\title{
Improvement of the Energy Density of Rice Husk Using Dry and Chemical Treated Torrefaction
}

\author{
Aytenew $\mathbf{G}^{1^{*}}$, Nigus $\mathbf{G}^{2}$ and Bedewi $\mathrm{B}^{1}$ \\ ${ }^{1}$ Department of Chemical Engineering, College of Engineering and Technology, Samara University, Samara, Afar, Ethiopia \\ ${ }^{2}$ Department of Chemical Engineering, Institute of Technology, Bahirdar University, Bahir Dar, Ethiopia
}

*Corresponding author: Aytenew Getaye, Lecturer, Department of Chemical Engineering, College of Engineering and Technology, Samara University, Samara, Afar, Ethiopia, Tel: +251921282359; E-mail: gaytenew2001@gmail.com

Received date: May 18, 2018; Accepted date: June 15, 2018; Published date: June 21, 2018

Copyright: (c) 2018 Getaye A, et al. This is an open-access article distributed under the terms of the Creative Commons Attribution License, which permits unrestricted use, distribution, and reproduction in any medium, provided the original author and source are credited.

\begin{abstract}
The main objective of this present study was to investigate the Torrefaction process of lignocellulose biomass rice husk produced in Ethiopia through dry and chemical treated Torrefaction. Torrefaction is a technology that a partial pyrolysis of biomass which is carried out under atmospheric pressure in a narrow temperature range of $200-300^{\circ} \mathrm{C}$ and under an inert environment which yields higher solid yield than pyrolysis. Three different Torre faction temperatures 230,255 and $280^{\circ} \mathrm{C}$ with three different holding times 20,40 and 60 minutes were considered using dry and chemical treated torrefaction. The result showed that a net reduction of the volatiles content, mass yield, moisture content, bulk density and atomic oxygen content correlate with increasing torrefaction temperature and reaction time, while atomic carbon content, higher heating value $(\mathrm{HHV})$, fixed carbon content and energy density increase with higher torrefaction temperatures in both treatment cases. So, torrefaction temperature and holding time had a significant effect on torrefaction process of rice husk. Based on the findings of this study, temperature of $280^{\circ} \mathrm{C}$ and $60 \mathrm{~min}$ for dry torrefaction and 280 with a residence time of $40 \mathrm{~min}$ for chemical treated torrefaction could be suggested for an effective and proper torrefaction process to recycle the agricultural biomass. The energy density of dry torrefaction was enhanced by $120 \%$ and chemical torrefaction was enhanced by $127.4 \%$. Therefore, the torrefied biomass becomes fuel sources which can be applied to replace with fossil fuel.
\end{abstract}

Keywords: Rice husk biomass; Chemical treatmented torrefaction; Dry torrefaction; Higher heating value; Energy density

\section{Introduction}

Biomass is expected to play a major role in the transition to renewable or sustainable energy production [1-4]. Woody and herbaceous biomasses are regarded as lignocellulose biomass, because their major organic mass fraction consists of cellulose, hemicellulose and lignin [5]. Bioenergy can be generated in different ways. It can be converted to a value-added liquids and gaseous products such as ethanol, synthesis gas, or bio-oil, or it can generate electricity via direct combustion, or gasification. Bioenergy is produced from organic materials, which are any form of biomass such as food crops, organic wastes, and forestry products [6]. Ethiopia has an abundance of forest resources, and these resources can provide a considerable amount biobased energy; however, utilizing these sources presents problems. Existing is either adapting this infrastructure to accommodate lower quality Biomass fuel, infrastructure for generating energy uses low moisture and oxygen content fuels, such as coal. The major challenge which can be very costly or creating a biomass product that can be utilized in a current steam generation or gasification plant. It is for this reason that methods to upgrade the biomass are being explored. The method being researched in this study is torrefaction. Torrefaction is a treatment process for biomass meant to reduce oxygen content and moisture absorption, which increases the energy content. Torrefaction is a thermo-chemical pretreatment process using biomass within a narrow temperature ranging from $200^{\circ} \mathrm{C}$ to $300^{\circ} \mathrm{C}$ [7]. Torrefaction process provides an alternative bioenergy resource since it increases energy density and reduces transport cost. This treatment is carried out under atmosphere conditions in a non-oxidizing environment and for a relatively long residence time [8]. A longer residence time up to an hour and higher temperatures increase the percentage of $\mathrm{CO}$ in noncondensable product gas $[9,10]$. Many researchers have observed regarding different types of biomass (bamboo, rice husk, or wood) with the similar result that mass yield decreases with longer residence time $[11,12]$. Repellin et al. [13] simulated the weight loss by calculating element contents of wood chips at torrefaction time and observed similar results In this study, selected biomass feed stock typical lignocellulose biomass ricehusk produced in Ethiopia was torrefied. The effect of chemical treated torrefaction pretreatment on the fuel properties of biomass was examined. In this study, selected biomass feed stock typical lignocellulose biomass ricehusk produced in Ethiopia was torrefied. The effect of chemical treated torrefaction pretreatment on the fuel properties of biomass was examined.

\section{Materials and Methods}

\section{Biomass preparation}

Rice husk obtained from local farmers was air dried to a moisture content of $10-15 \%$ (w. b). The husk was then fractionated to remove the large $(>4 \mathrm{~mm})$ and smaller chippes $(<2 \mathrm{~mm})$ with the use of vibrating screen separator. After screening, the husk was kept in dry atmosphere for further analysis. The raw and fractionated rice husk is shown in Figure 1. 


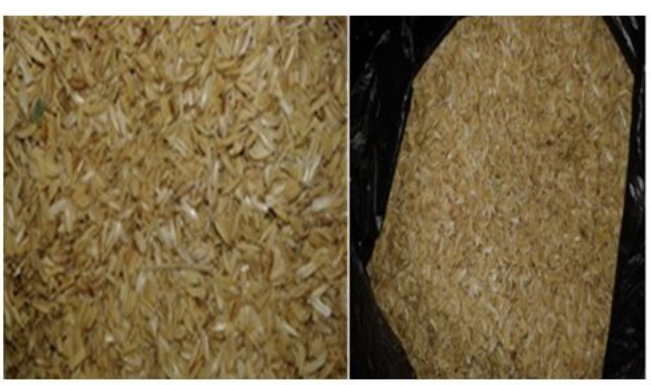

Figure 1: Raw and fractionated rice husk.

\section{Raw material characterization}

Rice husk from rice producing farmers was selected as feedstock for this study since it is the main agricultural crops in Ethiopia. The selection aims among others to utilize these available resources potential by improving the energy density using method i.e., chemical torrefaction. Proximate analyses of the raw feedstock and the torrefied rice husks were performed according to ASTM standards: ASTM E 871, ASTM E 872, and ASTM D 1102 for moisture content, volatile matter, and ash content, respectively.

\section{Experimental setup and description}

All experiments were carried out in a tubular reactor equipped with a hot plate heater (AM-5250 A), nitrogen cylinder, a thermocouple and a pressure gauge. A thermocouple for monitoring the reaction temperature (temperature of the sample and the reactor) is connected to the reactor by which the electrical duty of the heater is controlled manually. The reactor is connected to a nitrogen (99.99\% purity) cylinder via a valve to create inert atmosphere. After the samples were placed inside the tubular reactor, it was completely purged with nitrogen gas to remove all oxygen. The furnace/torrefied reactor was preheated to the desired temperature set point (Figure 2).

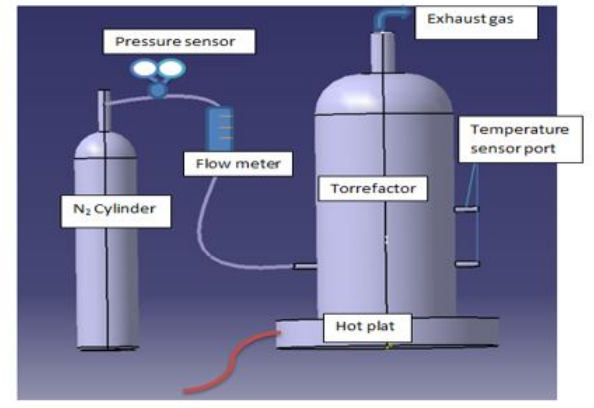

Figure 2: The theoretical experimental set up of torrefaction process.

Treatment time was said to begin when the furnace reached the desired set point. At the end of the treatment time, the biomass samples were pulled from the furnace and immediately placed in desiccators to prevent from moisture exposer and for further treatment and combustion. Once the crucible cooled to room temperature, the samples were weighed and analyzed with the respective test. The experimental set up for the torrefaction experiments are shown in Figures 2 and 3 and the general experimental frame work are shown in Figure 4.

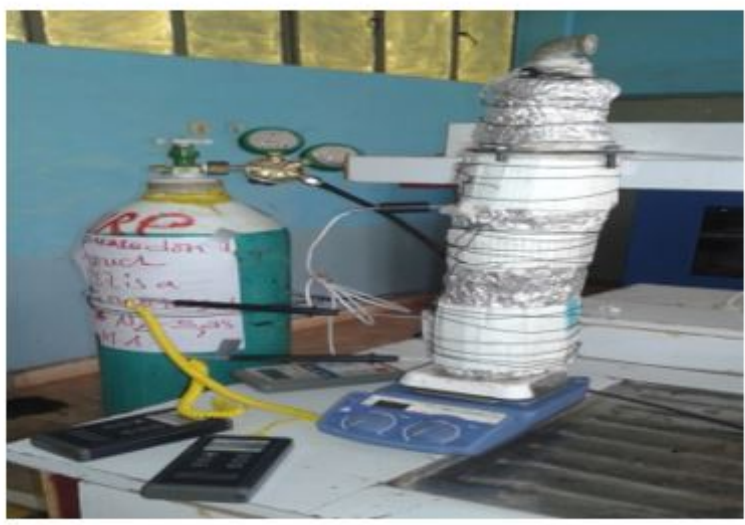

Figure 3: The actual experimental set up for torrefaction process.

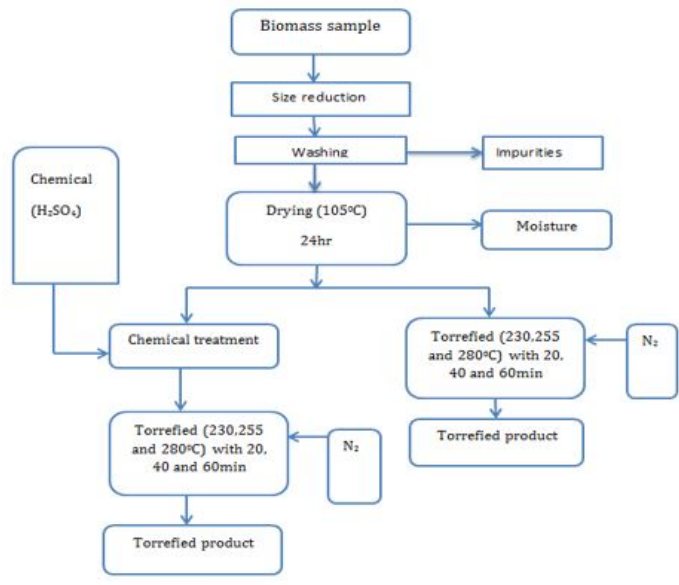

Figure 4: General experimental procedure for torrefaction process.

Proximate analysis: Proximate analysis which is a standardized procedure that gives an idea of the bulk components that make upgrade a fuel was done to determine the average of the percentage volatile matter content, percentage ash content, moisture content and percentage content of fixed carbon of the rice husk obtained from three replicates. The contents were found according to ASTM standards.

Mass yield: Mass yield can be calculated from the ratio of torrefied to raw solids [14]. The mass yield was calculated using the following equations Equation 1.

$$
\text { Mass yield }=\left(\frac{M f}{M i}\right) \times 100 \%
$$

Where: Mf is the final mass of biomass after torrefaction; Mi is initial mass of biomass before torrefaction (raw biomass). 
Page 3 of 6

Moisture content: Moisture content of each sample was found using oven drier. That is drying in the oven at $1050 \mathrm{C}$ for 24 hours and taken a mass difference before and after drying to the mass before drying.

$$
M C \%=\frac{(m i-m f)}{m i} \times 100
$$

Where: MC\% moisture content of sample, mi is initial mass of sample and $\mathrm{mf}$ is final mass of sample after oven dry.

Volatile content: The percentage volatile matter (VM\%) was determined by weighing of the dry rice husk sample in a crucible and placing it in an oven until a constant weight was obtained. The sample were then kept in a furnace at a temperature of $550^{\circ} \mathrm{C}$ for $10 \mathrm{~min}$ and weighed after cooling in a desiccator. The percentage volatile matter was then calculated using the Equation 3

$$
\% \mathrm{Vol}=\frac{[\mathrm{mi}]-[\mathrm{mf}]}{[\mathrm{mi}]} \times 100
$$

Where: \% Vol is percentage of volatile content, $\mathrm{mi}$ is initial mass of sample and $\mathrm{mf}$ is final mass of sample.

Ash content: Ash is the inorganic solid residue left after the fuel is completely burned. Its primary ingredients are silica, aluminum, iron, and calcium; small amounts of magnesium, titanium, sodium, and potassium may also be present. Ash content is determined by ASTM test protocol D-1102 for wood, E-1755-01 for other biomass, and D-3174 for coal. A $2 \mathrm{~g}$ sample in a standard condition was placed in a muffle furnace with the lid of the crucible removed. Temperature of the furnace is raised slowly from 550 to $575^{\circ} \mathrm{C}$ to avoid flaming for $3 \mathrm{hrs}$ Following this, the temperature is increased to $575^{\circ} \mathrm{C}$ and kept there until all the carbon is burnt. After that the sample was cooled and weighed. The percentage ash content was determined using the Equation 4.

$$
\% A s h=\frac{[M a s h]}{[M i]} \times 100
$$

Where: \% Ash is the percentage of Ash content, Mash is ash mass; Mi is initial mass of sample.

Fixed carbon content: The percentage fixed carbon (\%FC) was computed by subtracting the sum of $\% \mathrm{VM}$ and $\% \mathrm{AC}$ from 100 as shown in the Equation 5.

\section{FC $\%=100 \%$-Ash(dry)\%-Volatile $\%$ (5)}

Each test was performed in triplicate, and the average was reported. Results were given on a dry basis.

Elemental analysis (Ultimate composition): Elemental analysis of the biomass samples was performed using an elemental analyzer an "EA 1112 Flash CHNS-O- analyzer" at Addis Ababa University (AAU) Chemistry department. Conditions for the ultimate analysis were: Carrier gas flow rate of $120 \mathrm{ml} / \mathrm{min}$, reference flow rate $100 \mathrm{ml} / \mathrm{min}$, oxygen flow rate $250 \mathrm{ml} / \mathrm{min}$; furnace temperature of $900^{\circ} \mathrm{C}$ and oven temperature of $75^{\circ} \mathrm{C}$. A small sample was placed in the analyzer, and results for carbon, hydrogen, and nitrogen content were returned by the analyzer. Helium was used as a carrier gas. Rice husk samples with two repetitions were analyzed for each set of treatment and reported only the average values on a dry basis. Results were corrected for moisture content and reported on a dry basis. Oxygen was calculated by difference:

Oxygen $\%=100 \%$-carbon\%-hydrogen $\%$-nitrogen\%-as (6)
Energy content: Energy content can be described by using higher heating value (HHV) and Lower heating value (LHV). HHV is the most commonly used way of describing energy contents. The HHV from ultimate and proximate analysis of torrefied biomass was determined by using unified correlation proposed by Nhuchhen and Afzal.

$$
\mathrm{HHV}=0.1846 \mathrm{VM}+0.3525 \mathrm{FC} \text { (7) }
$$

Where: VM is volatile matter and FC is fixed carbon contents

$$
\text { HHV }=32.7934+0.0053 \mathrm{C}^{2}-0.5321 \mathrm{C}-2.8769 \mathrm{H}+0.0608 \mathrm{CH}-0.2401 \mathrm{~N}
$$
(8)

Energy density: Energy yield and Mass yield were used to calculate an energy density for the biomass samples. Torrefaction should be performed after transport to ensure the maximum amount of energy is moved per load. Biomass volume can change and be modeled as a function of moisture content [15].

$$
E D=\frac{Y \operatorname{energy}(\%)}{Y \operatorname{mass}(\%)}
$$

Where, ED is the energy density, \%Ymass is the percentage mass yield.

Hydrophobic properties: The equilibrium moisture content (EMC) of a material surrounded at least partially by air is the moisture content at which the material is neither gaining nor losing moisture. The value of the EMC depends on the material and the relative humidity and temperature of the air with which it is in contact. The speed at which it is approached depends on the properties of the material and the speed with which humidity is carried away or towards the material (e.g, diffusion in stagnant air or convection in moving air). Equilibrium moisture content (EMC) can be used as an indicator of the hydrophobicity of a solid [16]. Hydrophobic property of torrefied biomass is examined by water immersion test or by equilibrium moisture contents (EMC) studies [17]. Both water immersion and equilibrium moisture content test were performed in the study for hydrophobicity analysis. The equilibrium moisture content was analyzed by equilibrium moisture content analyzer (Figure 5).

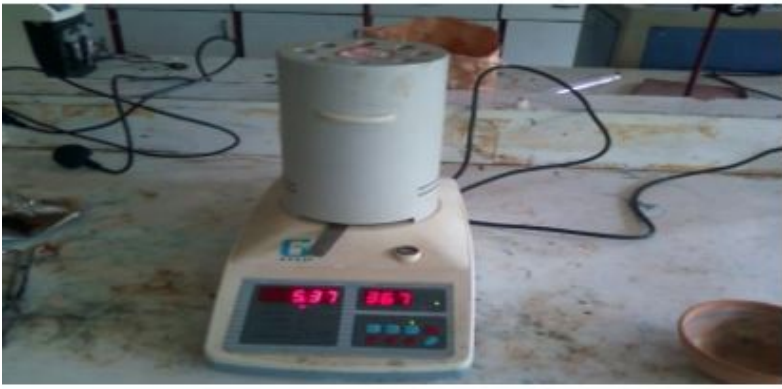

Figure 5: Equilibrium Moisture content analyzer.

Equilibrium Moisture Content (EMC), showing the amount of moisture that biomass has absorbed at a specific temperature, pressure and humidity. And the equilibrium moisture content analyzer calculates the EMC using Equation 10:

$$
E M C \%=\frac{(M e-M d)}{M d} \times 100
$$


Where Me is the mass of the sample at equilibrium with a humid atmosphere and $\mathrm{Md}$ is the mass of dry sample. The sample was measured at $79 \%$ relative humidity $(\mathrm{RH})$ and temperature of $25^{\circ} \mathrm{C}$.

Bulk density: Bulk density is the ratio of the mass of a material to its volume, and it plays a crucial role in the economic analysis of a bioenergy supply chain. It can be calculated by emersion of a known quantity (mass) of biomass to a known volume of water in graduated cylinder. And, the ratio of mass of biomass to the volume of water displaced is bulk density.

$$
\rho=\frac{m}{V}
$$

Where, is the density of biomass, $\mathrm{m}$ is mass of sample and $\mathrm{V}$ is the volume of water displaced

Thermo gravimetric analysis: Thermal gravimetric analysis (TGA) is a method of thermal analysis in which change in physical and chemical properties of materials measured as a function of increasing temperature (with constant heating rate), or as a function of time (with constant temperature and/or constant mass loss). The TGA instrument (BJ HENVEN Analysis (ATAT 2012)) as seen in, it continuously weighs and measure the sample as it was heated up to $1000^{\circ} \mathrm{C}$. The systems consist of a combustor and balance connected to a computer in order to record automatically every 30 second and a thermal meter records data every 1 second. Two samples (raw rice husk, and $280^{\circ} \mathrm{C}$ and $40 \mathrm{~min}$ treated) having $5 \mathrm{mg}$ weight for each sample were loaded separately. Once the $5 \mathrm{mg}$ sample was loaded to the balance, $10 \mathrm{ml} / \mathrm{min}$ nitrogen gas was purged to the sample port to create inert atmosphere, the temperature rise was set to $100 \mathrm{C} / \mathrm{min}$, and the final temperature was set to $1000^{\circ} \mathrm{C}$ and finally the sample was analyzed. The information that was obtained from TGA is in order to precede further investigation on the effect of torrefaction temperature on the thermal decompositions of the biomass raw materials to observe the torrefaction peaks or to clearly identify thermal degradations of raw biomasses as shown in Figure 6.

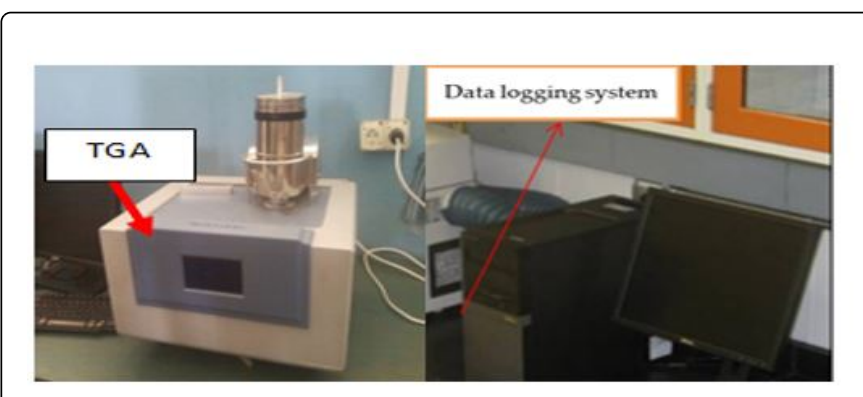

Figure 6: Thermo gravimetric Analyzer (TGA).

\section{Results and Discussion}

\section{Preliminary qualitative assessment}

Figures 7 and 8 shows, the surface morphology of dry and chemical treated and torrefied rice husk. As can be seen in the Figure 7, the color had changed with increasing torrefaction temperature, the surface morphology of the torrefied rice husk changed significantly, showing a gradually shrinking volume and turning from yellow to brown and then black. The visual difference of the biomass subjected to torrefaction is the color of the samples. Carbonization of the biomass increased with the intensity of torrefaction. Pelaez-Samaniego et al. reported that changes of color might be occurred due to the oxidation of phenolic compounds and the presence of sugars and amino acids during torrefaction process. As seen in Figure 8, chemical torrefaction of rice husk, the color change gradually from yellow to red and then turned to brown due to oxidation within the environment, finally after torrefaction, changed to deep black. As it has been discussing previously, this is due to the oxidation of phenolic compounds and the presence of sugars and amino acids during torrefaction. Since chemical treatment modifies the fiber structure, and dilute sulfuric acid is better used for surface modification, the fiber strictly modified for better carbonization that was the reason for its deep black after torrefaction.

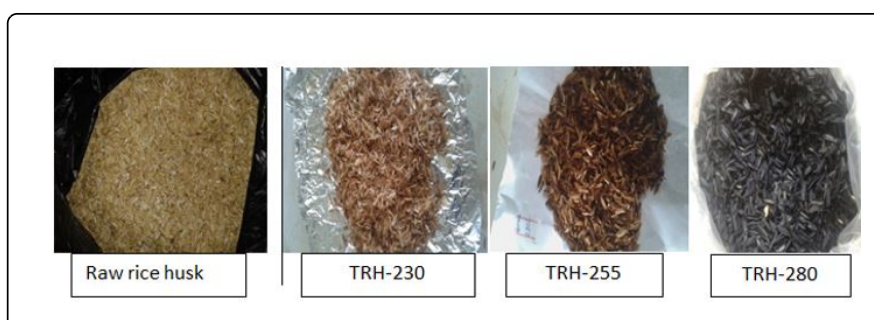

Figure 7: Effect of Torrefaction temperature on surface morphology of dry rice husk.

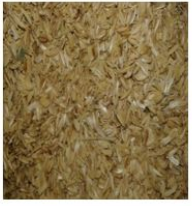

Treated husk

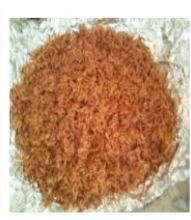

$280^{\circ} \mathrm{C}$ and $40 \mathrm{~min}$

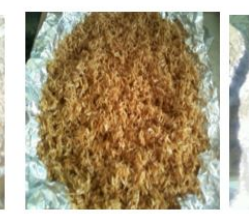

Raw Rice Husk

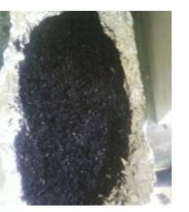

$2.5 \% \mathrm{H}_{2} \mathrm{SO}_{4}$
Figure 8: Effect of Torrefaction temperature on surface morphology of chemical treated torrefied rice husk sample.

\section{Mass yield}

Torrefaction temperature and torrefaction time had significant effect on mass yield. When the torrefaction temperature was $230^{\circ} \mathrm{C}$ and 20 min, the solid yield was $98.663 \%$ and $87.87 \%$ for dry and chemical treated torrefaction respectively. As the torrefaction temperature increased the solid yield decreased in both cases. When torrefaction temperature is higher than $255^{\circ} \mathrm{C}$, most of hemicellulose was decomposed, and the cellulose started to decompose, so the solid yield decreased quickly, at $280^{\circ} \mathrm{C}$ and 60 min solid yield became 74.263 and 70.1 for dry and chemical treated torrefaction respectively.

Increasing torrefaction temperature from 230 to $280^{\circ} \mathrm{C}$, the mass yield dropped gradually at the respective treatment time. This illustrates the effect of torrefaction temperature and holding time on the mass yield. This is in compliance with the expected results, since torrefaction involves the loss of both moisture and low energy density volatile matter from the sample of biomass. See Figures 9 and 10. 


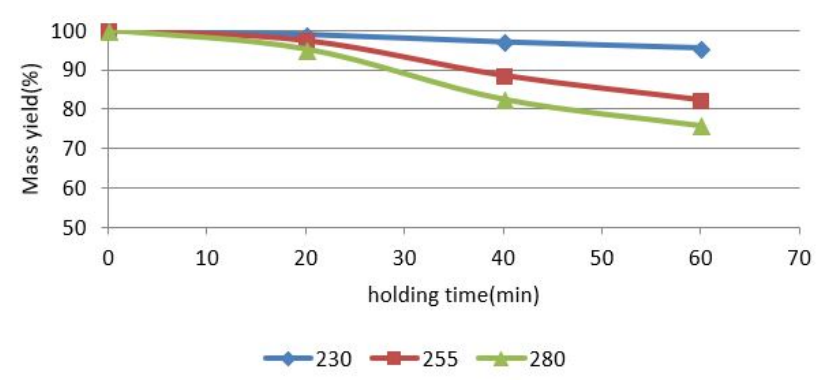

Figure 9: Effect of torrefaction temperature and holding time on mass yield of chemical treated torrefied rice husk.

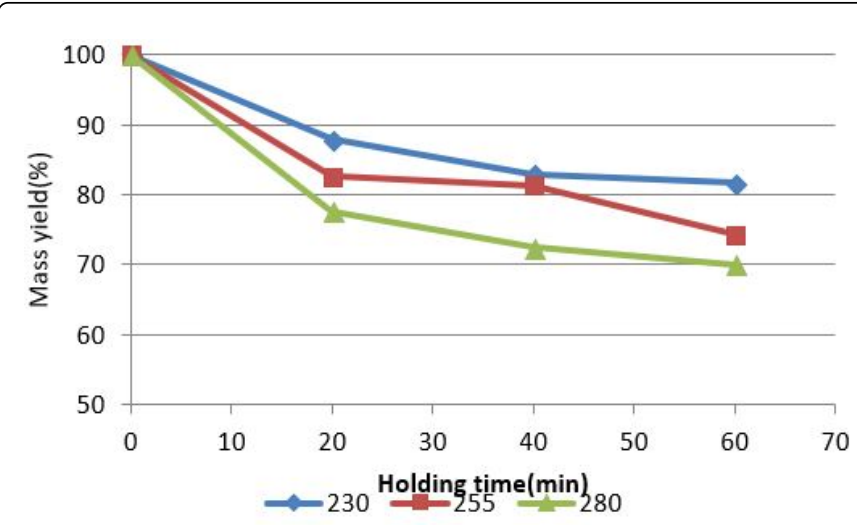

Figure 10: Effect of torrefaction temperature and holding time on mass yield of chemical treated torrefied rice husk.

\section{Fixed carbon}

Figures 11 and 12 presents the changes in the fixed carbon content in the rice husk torrefied at different temperatures and residence times for dry and chemical treated torrefaction respectively. The initial fixed carbon of the raw biomass was $13.86 \%$. Increasing the temperature (dry torrefaction) to $230,255,280^{\circ} \mathrm{C}$ and a $60 \mathrm{~min}$ residence time increased the fixed carbon content to about $17.20 \%, 26.40 \%$ and $34.07 \%$ (an increase of $24 \%, 90 \%$ and $145.84 \%$ from its original value). The maximum fixed carbon observed at $280^{\circ} \mathrm{C}$ and $60 \mathrm{~min}$ was about $34.07 \%$ (Figure 11). Whereas in chemical torrefaction, increasing the temperature to $230,255,280^{\circ} \mathrm{C}$ for $60 \mathrm{~min}$ residence time increased the fixed carbon content to about $33.57 \%, 38.30 \%$ and $37.77 \%$ (an increase of $142 \%, 176.33 \%$ and $172.51 \%$ from its original value) and torrefaction treatment at $280^{\circ} \mathrm{C}$ and $40 \mathrm{~min}$, the fixed carbon content became 43.73 (an increase of $215.5 \%$ from its original value). Therefore, chemical treated torrefaction increases the fixed carbon content even for the lower residence time. The reason behind is that during torrefaction at different temperature, the moisture content and volatile matter removed. So, the composition remained is purely ash and fixed carbon.

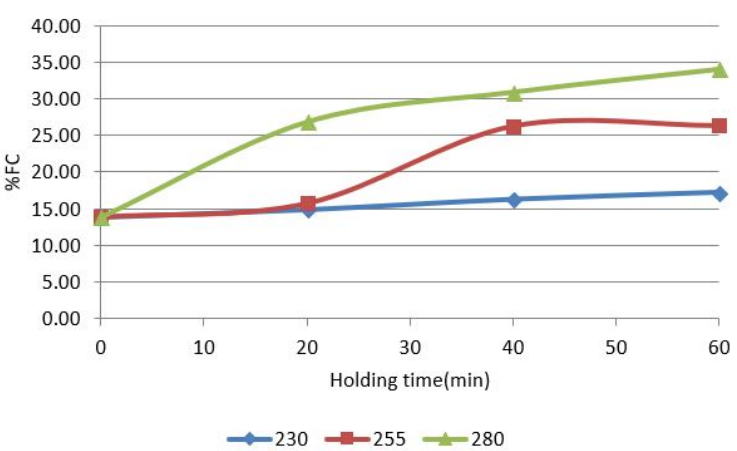

Figure 11: Effect of torrefaction temperature $\left({ }^{\circ} \mathrm{C}\right)$ and reaction time on fixed carbon yield of chemical treated torrefaction.

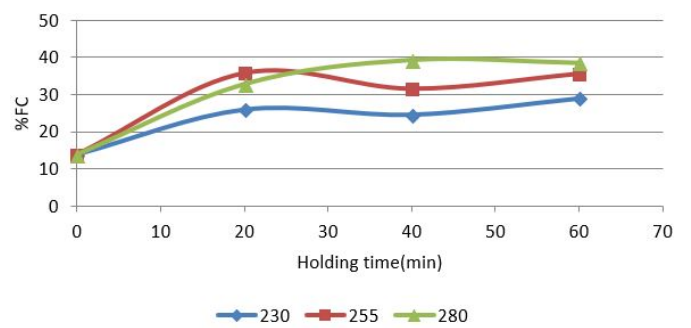

Figure 12: Effect of torrefaction temperature $\left({ }^{\circ} \mathrm{C}\right)$ and reaction time on fixed carbon yield of chemical treated torrefaction.

\section{Energy density}

The energy density was determined from the ratio of HHV of torrefied product to raw biomass. In line with HHV results, energy density increases for the torrefied biomass according to the increase in temperatures and residence time. The highest energy density yield was obtained with a resident time of $60 \mathrm{~min}$ and $280^{\circ} \mathrm{C}$ for dry torrefaction and $40 \mathrm{~min}$ and $280^{\circ} \mathrm{C}$ for chemical treated torrefaction. At those conditions, the energy density of dry and chemical treated torrefied rice husk was $120 \%$ and $127.4 \%$ respectively. As shown in Figures 13 and 14 a significant energy density yield was found at temperature between 230 to $280^{\circ} \mathrm{C}$. Bergman et al. [11] reported that energy density increases with torrefaction temperature because $\mathrm{C} / \mathrm{O}$ and $\mathrm{C} / \mathrm{H}$ ratios increase with rising temperatures. Upon torrefaction, biomass loses various compounds with high oxygen and hydrogen contents such as moisture $\left(\mathrm{H}_{2} \mathrm{O}\right), \mathrm{CH}_{3} \mathrm{COOH}, \mathrm{CH}_{3} \mathrm{OH}$, and $\mathrm{CO}_{2}$. This is particularly beneficial for gasification of biomass that contains a large amount of oxygen $[18,19]$.

This is because volatile and moisture content has reduced. The torrefaction process does not remove any part of the fixed carbon and ash content in biomass materials. Therefore, the energy density will be increasing according to temperature and residence time since energy density is proportional to fixed carbon contents. 
Page 6 of 6

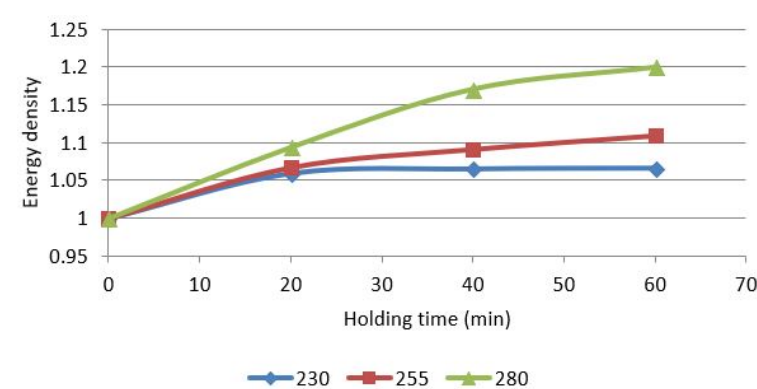

Figure 13: Effect of torrefaction temperature and holding time on energy density of chemical treated torrefied rice husk.

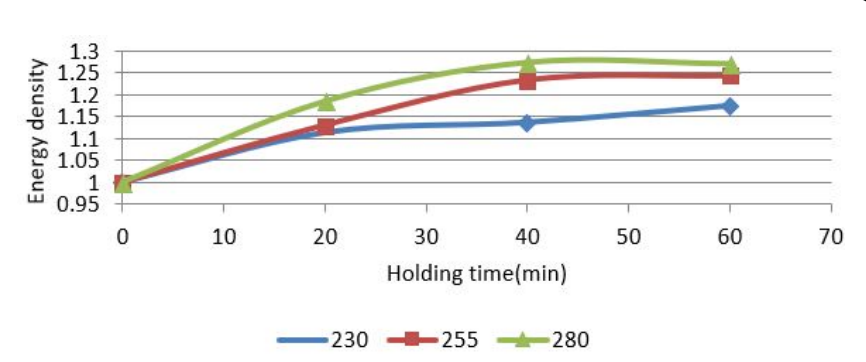

Figure 14: Effect of torrefaction temperature and holding time on energy density of chemical treated torrefied rice husk.

\section{Conclusion}

Dry and chemical treated torrefaction of rice husk was performed to enhance the energy contents or the bioenergy property. From the results obtained by torrefaction of rice husk, a net reduction of the, mass yield, moisture content, and atomic oxygen content correlate with increasing torrefaction temperature and reaction time, while atomic carbon content, higher heating value(HHV), fixed carbon content and energy density increase with higher torrefaction temperatures and time in both treatment cases. A mild torrefaction treatment of $280^{\circ} \mathrm{C}$ at 60 min for dry torrefaction and $280^{\circ} \mathrm{C}$ at $40 \mathrm{~min}$ for chemical treated torrefaction was found to be the optimal torrefaction conditions for improving the heating value, energy density and hydrophobicity characteristics of rice husk. The energy density of dry torfaction was improved by $120 \%$ and for chemical treated torrefaction it was enhanced by $127.4 \%$. Therefore, torrefaction is a new and important technology to recycle the waste biomass for energy purposes as a substitute of fossile fules as well as to reduce the volume of waste generated.

\section{References}

1. Bergman PCA, Kiel JHA (2005) Torrefaction for biomass upgrading. Published at 14th European Biomass Conference and Exhibition, Paris, France.
2. Batidzirai B, Mignot APR, Schakel WB, Junginger HM, Faaij APC (2013) Biomass torrefaction technology: Techno-economic status and future prospects. Energy 62: 196-214.

3. Basu P, Sadhukhan AK, Gupta P, Rao S, Dhungana A, et al. (2014) An experimental and theoretical investigation on torrefaction of a large wet wood particle. Bioresource Technology 159: 215-222.

4. Lee WJA (2012) comparative study on fuel characteristic and combustion behaviour of biomass fuel types. Journal of Korea Society of Waste Management 29: 421-430.

5. Chen WH, Kuo PC (2011) Torrefaction and co-torrefaction characterization of hemicellulose, cellulose and lignin as well as torrefaction of some basic constituents in biomass. Energy 36: 803-811.

6. Carter CL (2012) Physicochemical Properties and Thermal Decomposition of Torrefied Woody Biomass and Energy Crop. MSc Thesis.

7. Du SW, Chen WH, Lucas JA (2014) Pretreatment of biomass by torrefaction and carbonization for coal blend used in pulverized coal injection. Bioresource Technology 161: 333-339.

8. Pelaez-Samaniego MR, Yadama V, Garcia-Perez M, Lowell E, Armando GM (2014) Effect of temperature during wood torrefaction on the formation of lignin liquid intermediates. Journal of Analytical and Applied Pyrolysis 109: 222-233.

9. Ferro DT, Vigouroux V, Grimm A, Zanzi R (2004) Torrefaction of agricultural and forest residues, II- 0185-FA. Conference Publication 4, Cubasolar, Guantanamo, Cuba.

10. Chen WH, Lu KM, Lee WJ, Liu SH, Lin TC (2014) Non-oxidative and oxidative torrefaction characterization and SEM observations of fibrous and ligneous biomass. Applied Energy 114: 104-113.

11. Bergman PCA, Boersma A, Zwart RWR, Kiel JHA (2005) Development of torrefaction for biomass co-firing in existing coal-fired power stations "biocoal" ECN Report ECN-C-05-013.

12. Felfli FF, Luengo CA, Suárez JA, Beatón PA (2005) Wood briquette torrefaction. Energy for Sustainable Development 9: 19-22.

13. Repellin V, Govin A, Rolland M, Guyonnet R (2010) Modelling anhydrous weight loss of wood chips during torrefaction in a pilot kiln. Biomass and Bioenergy 34: 602-609.

14. Bridgeman TG, Shield I, Jones JM, Williams PT (2008) Torrefaction of reed canary grass, wheat straw and willow to enhance solid fuel qualities and combustion properties. Fuel 87: 844-885.

15. Tagawa A, Muramatsu Y, Nagasuna T, Kasai T (2002) Volume Change of Kidney Beans Soaking in Water. Transactions of the ASAE 45: 1505-1510.

16. Yan W, Acharjee TC, Coronella CJ, Vasquez VR (2009) Thermal treatment of lignocellulosic biomass. Environmental Progress and Sustainable Energy 28: 435-440.

17. Pimchuai A, Dutta A, Basu P (2010) Torrefaction of agriculture residue to enhance combustible properties. Energy Fuels 24: 4638-4645.

18. Prins MJ (2005) Thermodynamic analysis of biomass gasification and torrefaction. PhD Dissertation Technische Universiteit Eindhoven Netherlands.

19. Prins MJ, Ptasinski KJ, Janssen FJJG (2006) Torrefaction of Wood Part 1 Weight loss kinetics. Journal of Analytical and Applied Pyrolysis 98: 3026-3036. 